\title{
BESZÁMOLÓ A FARKAS FERENC NEMZETKÖZI TUDOMÁNYOS KONFERENCIA (FFISC) SZAKMAI MUNKÁJÁRÓL
}

A Pécsi Tudományegyetem Közgazdaságtudományi Karának Vezetés- és Szervezéstudományi Intézete (PTE KTK VSZI) 2018. június 7-8-án első alkalommal rendezte meg a Farkas Ferenc Nemzetközi Tudományos Konferenciát.

FARKAS Ferenc professzor (1949-2016), konferenciánk névadója, karunk kiemelkedő formátumú kutatója és oktatója, valamint többek között a Közgazdaságtudományi Kar dékánja és a Pécsi Tudományegyetem rektorhelyettese volt, akinek hazai és nemzetközi tudományos kutatásai, publikációi előadásai érintették a menedzsment számos irányvonalát, emelve ezzel a szakma színvonalát. Farkas Ferenc egyetemi oktatóként 44 éven keresztül dolgozott, kutatott, s vett részt az egyetemi élet formálásában a Pécsi Tudományegyetem Közgazdaságtudományi Karán. Oktatási tevékenysége kiterjedt a vezetés, szervezeti viselkedés, a változások vezetése és az emberierőforrás-menedzsment területeire. Részt vett e tudásterületek hazai tananyagainak kidolgozásában, az azokat hasznosító szakok, szakirányok kialakításában, fejlesztésében. A doktori iskolák aktív résztvevőjeként számos hazai és külföldi PhD-hallgató témavezetője volt. Kiválóan kamatoztatta elméleti tudását egyetemi vezetői tisztségeinek gyakorlásakor. A hazai és külföldi egyetemeken tett látogatásai során kialakított tartós kapcsolataiból itthoni kollégái és hallgatói is profitálhattak.

Tudományos tevékenységének eredményeképpen több mint 250 publikáció és közel 20 tudományos szakkönyv született, amelyek középpontjában az oktatott diszciplínák, valamint a szervezeti tudás menedzselésének problémái álltak. Hazai és nemzetközi konferenciák rendszeres résztvevője volt, emellett szervezőként, kutatási projektek vezetőjeként fontos tudományszervező munkát is folytatott. Tagja volt számos hazai és nemzetközi szakmai folyóirat szerkesztőbizottságának, magyar és nemzetközi szervezeteknek, valamint tudományos testületeknek. Különböző kari, illetve egyetemi vezetői pozíciókat betöltve évtizedeken át szolgálta a Közgazdaságtudományi Kart és a Pécsi Tudományegyetemet. Kimagasló teljesítményéért több alkalommal részesült magas elismerésben és kormány kitüntetésben. A nonprofit/civil szervezetekben egyesületek, alapítványok vezetőjeként, kuratóriumok tagjaként hasznosította vezetői, menedzseri szaktudását. Konferenciánk elnevezésével Professzor úrnak kívánt emléket állítani, továbbá szellemi örökségét kívánja ápolni és hosszú távon fenntartani.

Kétnapos konferenciánk alatt magyar és angol nyelvü szekcióknak is helyet adtunk. A konferencián 16 ország szakemberei vettek részt, s 125 fó tisztelte meg jelenlétével. Az érdeklődést alátámasztó adat, hogy 95 szerző tollából 61 tanulmány született, amelyeket egy tanulmánykötetben publikáltunk. A kétnapos konferencia keretén belül 10 szekcióban hangzottak el magyar és angol nyelvü elöadások, ahol elismert oktatók és kutatók osztották meg egymással gondolataikat, legfrissebb kutatási eredményeiket a tudományterület aktualitásairól. További célunk ezzel a tudományos összejövetellel az volt, hogy fórumot hozzunk létre a hazai és nemzetközi oktatóknak, kutatóknak, gyakorlatban dolgozó kollégáknak, PhD-hallgatóknak, hogy bemutathassák kutatási eredményeiket, ezáltal kívántuk elősegíteni a szakmai kapcsolatok létrejöttét, ápolását, illetve a további közös kutatás alapjainak megteremtését, a közös gondolkodás elindítását.

Nagy megtiszteltetés volt számunkra, hogy a konferencia védnökei Geert HOFSTEDE (Professor Emeritus Maastricht University, Hollandia, az MTA tiszteletbeli tagja, a Pécsi Tudományegyetem díszdoktora, világszerte a nemzeti és szervezeti kultúrák interakcióinak elismert kutatója) és BÉLYÁCZ Iván (DSc akadémikus, egyetemi tanár, az MTA rendes tagja, a tőkefinanszírozás és az amortizáció neves kutatója) elfogadták felkérésünket, és részvételükkel emelték konferenciánk színvonalát. A konferencia szervezeti védnöki tisztét a Magyar Rektori Konferencia vállalta, míg a szakmai együttmüködés részeként a konferencia Best Paper-jeinek megjelentetését a Vezetéstudomány szerkesztősége fogadta be.

A szerkesztői feladatokat ellátó kollégák kiválasztása mellett Farkas Ferenc Professzor Úr egyéniségére és kiemelkedő alakjára tekintettel döntött úgy a Szervező Bizottság, hogy egyedi template-t alakít ki útmutatóként a tanulmányok elkészítéséhez. A legkiválóbb munkák kiválasztásának minőségbiztosítása érdekében a tudományos folyóiratok által alkalmazott double blind review megközelítését választotta a Konferencia Szerkesztő Bizottsága az írásművek értékelésére. A konferenciára előzetesen beérkezett 65 tanulmány esetében a review folyamatot összesen 34 lektor segítette. A lektorok kiválasztásánál az adott tématerülethez való hozzáértés az elsődleges szempont, emellett egy-két esetet kivéve mindenki tudományos fokozattal rendelkezett. A konferencián való bemutatás és a valódi vitagenerálás szem előtt tartása miatt elvárásként fogalmazódott meg továbbá az is, hogy a szekcióvezetésre felkért neves szakemberek is előzetesen részletes betekintést nyerjenek az előadásra szánt anyagokba. A Konferenciához kapcsolódó lektori és reviewer-i munka során a téma illesztése és tartalmi vonatkozásai kapcsán számos esetben került sor a bírálói megjegyzések alapján végrehajtott javítások utáni újbóli áttekintésre, míg 9 tervezetnél a bírálók véleménye alapján, vagy olyan jelentős átalakításra lett volna szükség, amelyet a szerző nem 
tudott vállalni rövid határidővel, vagy pedig a bírálók nem javasoltak publikálásra.

A bírálatok után a legjobb tanulmányok kiválasztásakor a Szerkesztő Bizottság felkért professzori köre olyan értékelési metódust alkalmazott, melynek fókusza egyrészt a Vezetéstudomány célkitűzésének való megfelelésből, másrészt Farkas Ferenc Professzor szakmai és emberi törekvéseinek figyelembevételéből, harmadrészt pedig a tudományterülethez való hozzájárulás potenciáljából állt. A szelekciós munka nehéz feladatot jelentett, mindezek végeztével a Bizottsági tagok egyéni véleményének szintetizálását követően a 3 főszerkesztő egymástól függetlenül készítette el a saját javaslatát a Best Paper Award-ra az $56 \mathrm{db}$ anonim tanulmány és a bírálatok birtokában. A közös listára 17 tanulmány került, amelyek közül a két napos végső kiválasztási folyamat eredményeképpen az anonim és független bírálati szempontokat szem elött tartva jött létre az 5 magyar és 2 angol nyelvü tanulmányt tartalmazó Best Paper Award lista. A Vezetéstudomány folyóirat szerkesztőségével történt előzetes megegyezés okán ezek a cikkek kizárólag itt kerülnek majd első közlésre, így a konferenciakötetben 46 teljes tanulmány kapott helyet, a legszínvonalasabb 7 írásmü absztraktjával együtt. Emellett további 8 esetben biztosított lehetőséget a Szervező Bizottság a csak az absztrakttal történő befogadásra és a Konferencián történő megjelenésre. A Best Paper Awardot elnyert tanulmányok ezt követően átestek a Vezetéstudomány szokásos minősítő folyamatán, azaz a minimum két (egyes esetekben három) anonim bíráló viszszajelzése alapján kis mértékben még módosítani kellett a cikkeket.

Ebben a számban Balogh Gábor és Karoliny Mártonné cikke azt vizsgálja, hogy milyen HR- és vezetői feladatot jelentenek a korosodó munkavállalók speciális igényei, illetve a különböző generációk együttélése a munkahelyen milyen kihívásokat jelent. Szabó-Bálint Brigitta bemutatja azokat a karriermenedzsment-eszközöket, amelyek a munkavállalói sikert mozdítják elö. Bencsik Andrea és szerzőtársai azt vizsgálják, hogy milyen is a jó vezető az etikus viselkedést központba állítva. Márta Annette gondolatmenetének középpontja az, hogy az angol nyelv vált a tudományos világ lingua francájává, ez számos új kihívást generált az angolt nem anyanyelvként beszélök számára: a cikk ennek következményeit vizsgálja. Végül, László Gyula és Sipos Norbert az érdekegyeztetés szükségességét elemzi annak ismeretében, hogy a munkavállaló és a munkáltató között óhatatlanul aszimmetrikus a viszony.

A tudományos kutatómunkák bemutatása mellett, külön örömünkre szolgált, hogy a konferencia keretén belül rendezték meg a MTA Gazdálkodástudományi Bizottság kihelyezett ülését Bakacsi Gyula professzor elnökletével, amelyen a pécsi Vezetéstudományi Mühely bemutatkozására is sor kerülhetett.

Végül, Jarjabka Ákos (Pécsi Tudományegyetem Közgazdaságtudományi Kar Vezetés- és Szervezéstudományi Inté- zet, igazgató) 2018. június 7-én elhangzott nyitóbeszédének magyar fordítását az alábbiakban, változatás nélkül közöljük:

\section{„Tisztelt Rektor Úr, Dékán Úr, Elnök Úr, Védnök urak, kedves Meghívottak, Hölgyeim és Uraim!}

A Nemzetközi Tudományos Konferencia ötlete szinte akkor fogalmazódott meg a Pécsi Tudományegyetem Közgazdaságtudományi Kar Vezetés- és Szervezéstudományi Intézet oktatói közösségében, amikor 2016 októberében elvesztettük Intézetünk vezető professzorát, Farkas Ferencet. Tudtuk, hogy egy ilyen formátumú vezető, oktató, mentor és menedzser neve és vele mentalitása nem maradhat nyom nélkül, ezért már 2017-ben megszerveztünk a hazai társegyetemek oktatói részvételével egy emlékkonferenciát Farkas professzor tiszteletére, majd létrehoztuk a Farkas Ferenc emlék- és ösztöndíjat azon fiatal oktatók és hallgatók számára, akik tovább kívánják vinni Professzor Úr szellemiségét.

Ám a legfontosabb elem ekkor még hiányzott: egy olyan tudományos összejövetel, mely hosszú távon fenntartható módon hagyományt teremt, ahol a világból érkezett tudósok és fiatal kutatók találkozhatnak, eszmét cserélhetnek oly módon, ahogyan az Farkas Professzor célja is volt.

Örülök, hogy most itt állhatok Önök elött és bejelenthetem, hogy erőfeszítéseinket siker koronázta és életre tudtuk hívni ezt a nemzetközi tudományos fórumot olyan prominens képviselőkkel és érdeklődés mellett, ahogyan azt eleinte remélni sem mertük. Külön köszönet Schepp Dékán Úrnak, hogy az első pillanattól kezdve az elképzelés mellé állt, a Magyar Rektori Konferenciának, a Magyar Tudományos Akadémia vezető tagjainak és a Vezetéstudomány folyóirat szerkesztőségének, hogy védnökségükkel befogadták az elképzelésünket, és speciális köszönetem Hofstede Professzornak, hogy védnöki jelenlétével emeli a konferencia jelentőségét.

Legyenek ezek a napok a tudomány ünnepnapjai minden évben, érezzék jól magukat Pécsen. A konferenciát ezennel megnyitom!"

A konferencia alatt készült képgaléria, videofelvétel és a tanulmánykötet a honlapunkon elérhetö a http://ktk.pte. hu/ffkonf2018/konferencia címen.

Köszönjük Mindenkinek a részvételt, akik jelenlétükkel, színvonalas előadásukkal hozzájárultak konferenciánk sikeréhez, és várjuk őket és más érdeklődőt is a 2. FFISC-re!

A konferencia szervezői nevében: dr. Jarjabka Ákos

Pécsi Tudományegyetem Közgazdaságtudományi Kar Vezetés- és Szervezéstudományi Intézet

Összeállították: dr. Sipos Norbert és Venczel-Szakó Tímea 